\title{
Trends in frequency and prevalence of oral cancer and oral squamous cell carcinoma in Mexicans. A 20 years retrospective study
}

\author{
Luis-Alberto Gaitán-Cepeda, Adriana-Graciela Peniche-Becerra, Daniel Quezada-Rivera
}

Oral Pathology Laboratory, Postgraduate and Research Division, Dental School, National Autonomous University of México

Correspondence:

Laboratorio de Patología Oral,

División de Estudios de Postgrado e Investigación,

Facultad de Odontología, UNAM.

Circuito Institutos, $s / n$, Ciudad Universitaria,

Coyoacán, 04510, México, D.F. México.

lgaitan@servidor.unam.mx

\begin{abstract}
Gaitán-Cepeda LA, Peniche-Becerra AG, Quezada-Rivera D. Trends in frequency and prevalence of oral cancer and oral squamous cell carcinoma in Mexicans. A 20 years retrospective study. Med Oral Patol Oral Cir Bucal. 2011 Jan 1;16 (1):e1-5.

http://www.medicinaoral.com/medoralfree01/v16i1/medoralv16ilp1.pdf
\end{abstract}

Received: 24-11-2009 Accepted: 05-04-2010

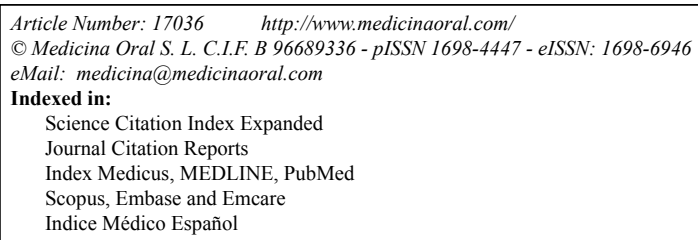

Indice Médico Español

\begin{abstract}
Objective. To establish the time trends of the frequency and prevalence of oral cavity cancer in regard to age and gender in a 20-years (time period 1989 - 2008) cohort of Mexicans. Design and Setting. 13,235 head and neck biopsies from the archive of the Oral Pathology Laboratory, Dental School, National Autonomous University of Mexico were revised. The cases with diagnoses of oral cancer were selected. Gender and age at diagnosis was obtained from medical records. The frequency and prevalence of oral cavity cancer and oral squamous cell carcinoma were assessed biannually in regard to the total number of population served by the oral pathology laboratory. The statistical significance of trends was established using the linear logistic regression (curve estimation) test (s 0.05). Results. 298 cases (138 males; 160 females) of oral cancer were included; 167 ( 92 females; 75 males; female:male ratio: 1.1:1) corresponded to oral squamous cell carcinoma. From 1989 to 2008 the prevalence of oral cancer and oral squamous cell carcinoma increased 200\% (s 0.05 ) and 100\% (s 0.000 ) respectively. The increase of frequency and prevalence was observed in both genders however only in females was significant (s 0.000$)$. We do not identify changes in the age at diagnosis. Conclusions. Oral cancer, specifically oral squamous cell carcinoma, has increase in Mexicans females in the last 20 years.
\end{abstract}

Key words: Oral cancer, squamous cell carcinoma, demographics characteristics, trends, Mexicans.

\section{Introduction}

An increase in the people less than 40 years suffering cancer, including the oral cavity cancer (OCC) has been reported in the last decade (1). Even more, the presence of oral squamous cell carcinoma (OSCC) in young people without a history of exposure to carcinogenic risks factors has been reported $(2,3)$. However scientific lit- erature about if Latin-American people shows similar demographical behavior is scarce. To contribute to better knowledge of this important issue the principal objective of this report was to establish the time trend of the frequency and the prevalence of OCC and OSCC in regard to age at moment of diagnosis and gender in a 20-years Mexican cohort . 


\section{Materials and Methods}

The archive of the Oral Pathology Laboratory of the Dental School, National Autonomous University of México was revised from January 1989 to December 2008. The cases with diagnosis of OCC were identified and selected. Only the cases with histological slides and/or sufficient biological material embedded in paraffin to be cut at $5 \mu$ and stained with Hematoxylin - Eosin technique were included. The histological slides of the selected cases were observed by two experts in head and neck malignancies (LAGC, DQR) to confirm their diagnostic or be re-diagnosed. All cases with a confirmed diagnosis of OCC and OSCC were selected.

The gender and age at diagnoses were obtained from medical records. Metastatic tumors were excluded. The biannual distribution frequency of OCC and OSCC in each gender was obtained. The prevalence was established in regard to the population that is served by the oral pathology laboratory. The oral pathology laboratory is the only service at the Dental school of the National Autonomous University of México that offers histopathological diagnosis of head and neck lesions. Therefore all the suspicious cases (clinical or biopsies) of oral disease or oral lesions are referred to our oral pathology service to be diagnosed. In consequence the prevalence of OCC and OSCC were established as follows: prevalence $=$ number of cases/total patients served at dental school x100 (\%). The total of patients annually attended was obtained from the archives of the Dental school and from the university yearbook (4). The mean of the age of the patients suffering OCC and OSCC was assessed biannually. The trend of frequency and prevalence of OCC and OSCC as soon as the mean of the age at moment of diagnosis in regard to gender was assessed using a logistic lineal regression (temporal curve) test (s $<0.05)$ (SPSS 13.0® software, Chicago, USA).

\section{Results}

From January 1989 to December 2008 our oral pathology service processed 13,235 head and neck biopsies (age mean 35 years; Standard Deviation [SD] \pm 4 ). 298 (2.25\%) cases (138 males, age mean $55.6 \mathrm{SD} \pm 10.8 ; 160$ females, age mean $54.4 \mathrm{SD} \pm 6.2$ ) were OCC. A trend towards increase the frequency of OCC was observes; from 10 cases in 1898-1990 to 37 cases in 2007-2008. This means an increase of $270 \%$ (s 0.007 ). This trend to increase was observes in both genders (Table 1) however only in females was significant (s 0.001). In the

Table 1. Demographical data of a cohort of Mexicans (1989 - 2008) suffering oral cancer and oral squamous cell carcinoma.

\begin{tabular}{|c|c|c|c|c|c|c|c|c|c|c|}
\hline YEAR & \multicolumn{3}{|c|}{ PATIENTS* } & \multicolumn{3}{c|}{ CASES OF ORAL CANCER } & \multicolumn{3}{c|}{ CASES OF OSCC } \\
\hline & TOTAL & + & 0 & TOTAL & + & 0 & TOTAL & + & 0 \\
\hline $1989-1990$ & 47,750 & 28,650 & 19,100 & 10 & $\begin{array}{c}6 \\
(50.8)\end{array}$ & $\begin{array}{c}4 \\
(58.5)\end{array}$ & 6 & $\begin{array}{c}4 \\
(56)\end{array}$ & $\begin{array}{c}2 \\
(60.5)\end{array}$ \\
\hline $1991-1992$ & 53,814 & 32,288 & 21,526 & 17 & $\begin{array}{c}7 \\
(59.1)\end{array}$ & $\begin{array}{c}10 \\
(54.9)\end{array}$ & 11 & $\begin{array}{c}4 \\
(58.1)\end{array}$ & $\begin{array}{c}7 \\
(66.5)\end{array}$ \\
\hline $1993-1994$ & 68,947 & 41,368 & 27,579 & 24 & $\begin{array}{c}11 \\
(47.3)\end{array}$ & $\begin{array}{c}13 \\
(52.3)\end{array}$ & 14 & $\begin{array}{c}7 \\
(51.2)\end{array}$ & $\begin{array}{c}7 \\
(62.6)\end{array}$ \\
\hline $1995-1996$ & 80,813 & 48,487 & 32,326 & 14 & $\begin{array}{c}8 \\
(60.8)\end{array}$ & $\begin{array}{c}6 \\
(53.2)\end{array}$ & 5 & $\begin{array}{c}3 \\
(57.5)\end{array}$ & $\begin{array}{c}2 \\
(61)\end{array}$ \\
\hline $1997-1998$ & 99,469 & 59,681 & 39,788 & 31 & $\begin{array}{c}15 \\
(50)\end{array}$ & $\begin{array}{c}16 \\
(48.8)\end{array}$ & 29 & $\begin{array}{c}14 \\
(55.5)\end{array}$ & $\begin{array}{c}15 \\
(58.9)\end{array}$ \\
\hline $1999-2000$ & 47,853 & 28,711 & 19,142 & 16 & $\begin{array}{c}12 \\
(56.5)\end{array}$ & $\begin{array}{c}4 \\
(74)\end{array}$ & 9 & $\begin{array}{c}7 \\
(51.7)\end{array}$ & $\begin{array}{c}2 \\
(77.5)\end{array}$ \\
\hline $2001-2002$ & 65,505 & 38,154 & 25,436 & 52 & $\begin{array}{c}27 \\
(55.1)\end{array}$ & $\begin{array}{c}25 \\
(56.9)\end{array}$ & 28 & $\begin{array}{c}17 \\
(60.1)\end{array}$ & $\begin{array}{c}11 \\
(55.9)\end{array}$ \\
\hline $2003-2004$ & 63,590 & 38,154 & 25,436 & 51 & $\begin{array}{c}22 \\
(40)\end{array}$ & $\begin{array}{c}29 \\
(53.6)\end{array}$ & 26 & $\begin{array}{c}12 \\
(62.5)\end{array}$ & $\begin{array}{c}14 \\
(57)\end{array}$ \\
\hline $2005-2660$ & 55,683 & 33,409 & 22,274 & 46 & $\begin{array}{c}30 \\
(58.8)\end{array}$ & $\begin{array}{c}16 \\
(47.5)\end{array}$ & 24 & $\begin{array}{c}14 \\
(67.4)\end{array}$ & $\begin{array}{c}10 \\
(47.6)\end{array}$ \\
\hline $2007-2880$ & 54,058 & 32,434 & 21,624 & 37 & $\begin{array}{c}22 \\
(62.2)\end{array}$ & $\begin{array}{c}15 \\
(56.7)\end{array}$ & 15 & $\begin{array}{c}10 \\
(79.1)\end{array}$ & $\begin{array}{c}5 \\
(65.6)\end{array}$ \\
\hline TOTAL & 637,482 & 385,760 & 251,722 & 298 & $\begin{array}{c}160 \\
(54.4)\end{array}$ & $\begin{array}{c}138 \\
(55.6)\end{array}$ & 167 & $\begin{array}{c}92 \\
(59.9)\end{array}$ & $\begin{array}{c}75 \\
(61.3)\end{array}$ \\
\hline
\end{tabular}

*= TOTAL OF PATIENTS ATTENDING IN THE DENTAL CLINICS OF THE DENTAL SCHOOL, NATIONAL AUTONOMOUS UNIVERSITY OF MÉXICO (Ref 4); OSCC= ORAL SQUAMOUS CARCINOMA CELL OF THE ORAL CAVITY; ( ) = MEAN OF THE AGE AT DIAGNOSIS IN YEARS; $q=$ FEMALES; $\hat{\gamma}=$ MALES. 
same period of time (January 1989 to December 2008) were attending 637,482 patients in the dental clinics of the Dental School, therefore the prevalence of OCC was $0.04 \%$. The prevalence of OCC increases $200 \%$ from $0.02 \%$ in $1989-1990$ to $0.6 \%$ in $2007-2008$ (s 0.01 ). The trend to increase was significant in both genders: females s 0.004; males s 0.04 (Figure 1 and Table 2). In regard to the age at diagnoses, females increase from 50.8 in $1989-1990$ to 62.2 years in $2007-2008$. On the other hand the mean of the age in males diminish from 58.5 in 1989-1990 to 56.7 years in 2007-2008. In both cases the trend was not significant.

There were 167 cases of OSCC (92 females; 75 males; female:male ratio: 1.1:1). The cumulative cases of OSCC from 1989 to 1998 were 65; whereas from 1999 to 2008 were 102 cases (Table 1). It represents an increase of
$56.9 \%$ in 10 years (s 0.09 ). The time trend towards to increase the number of cases of OSCC was significant in females (s 0.02). The prevalence of OSCC in 19891990 was $0.01 \%$; in $1993-1994$ was $0.02 \%$; in $2001-2002$ was $0.04 \%$ and in $2007-2008$ was $0.02 \%$. This data represents an increase of $100 \%$ (Table 2 and figure 2). In spite of the increase was observes in both genders, only in females was significant (s 0.000).

The females suffering OSCC had a mean of the age at diagnosis of 58.4 years while in the males was 52.0. The women suffering OSCC showed a trend toward increase the age at moment of diagnosis: from 56 years in 1989 - 1990 to 79.1 in 2007 - 2008; an increase of 23 years (s 0.1 ). The age of male patients suffering OSCC slightly increase, from 60.5 years old in 1989 - 1990 to 65.6 in 2007 - 2008; this trend was not significant (s 0.467).

Table 2. Prevalence per year of cases of cancer of the oral cavity and cases of squamous cell carcinoma of the oral cavity in a cohort of Mexicans.

\begin{tabular}{|c|c|c|c|c|c|c|}
\hline \multirow[t]{3}{*}{ YEAR } & \multirow{2}{*}{\multicolumn{3}{|c|}{$\begin{array}{c}\text { PREVALENCE OF ORAL } \\
\text { CANCER } \\
\% \\
\end{array}$}} & \multicolumn{3}{|c|}{ PREVALENCE OF OSCC } \\
\hline & & & & & $\%$ & \\
\hline & TOTAL & $\underline{9}$ & a & TOTAL & 운 & $\lesssim$ \\
\hline $\begin{array}{l}1989 \text { - } \\
1990\end{array}$ & 0.02 & 0.02 & 0.02 & 0.01 & 0.01 & 0.01 \\
\hline $\begin{array}{l}1991 \text { - } \\
1992\end{array}$ & 0.03 & 0.02 & 0.04 & 0.02 & 0.01 & 0.02 \\
\hline $\begin{array}{l}1993- \\
1994\end{array}$ & 0.03 & 0.02 & 0.04 & 0.02 & 0.01 & 0.02 \\
\hline $\begin{array}{l}1995 \text { - } \\
1996\end{array}$ & 0.01 & 0.01 & 0.01 & 0.006 & 0.006 & 0.006 \\
\hline $\begin{array}{l}1997 \text { - } \\
1998\end{array}$ & 0.03 & 0.02 & 0.04 & 0.02 & 0.02 & 0.03 \\
\hline $\begin{array}{l}1999 \text { - } \\
2000\end{array}$ & 0.03 & 0.04 & 0.02 & 0.01 & 0.02 & 0.01 \\
\hline $\begin{array}{l}2001 \text { - } \\
2002\end{array}$ & 0.07 & 0.06 & 0.1 & 0.04 & 0.03 & 0.04 \\
\hline $\begin{array}{l}2003= \\
2004\end{array}$ & 0.08 & 0.08 & 0.07 & 0.04 & 0.03 & 0.05 \\
\hline $\begin{array}{l}2005= \\
2006\end{array}$ & 0.08 & 0.08 & 0.07 & 0.04 & 0.04 & 0.04 \\
\hline $\begin{array}{l}2007= \\
2008\end{array}$ & 0.06 & 0.06 & 0.06 & 0.02 & 0.03 & 0.02 \\
\hline TOTAL & 0.04 & 0.04 & 0.05 & 0.02 & 0.02 & 0.02 \\
\hline
\end{tabular}


Prevalence (\%)

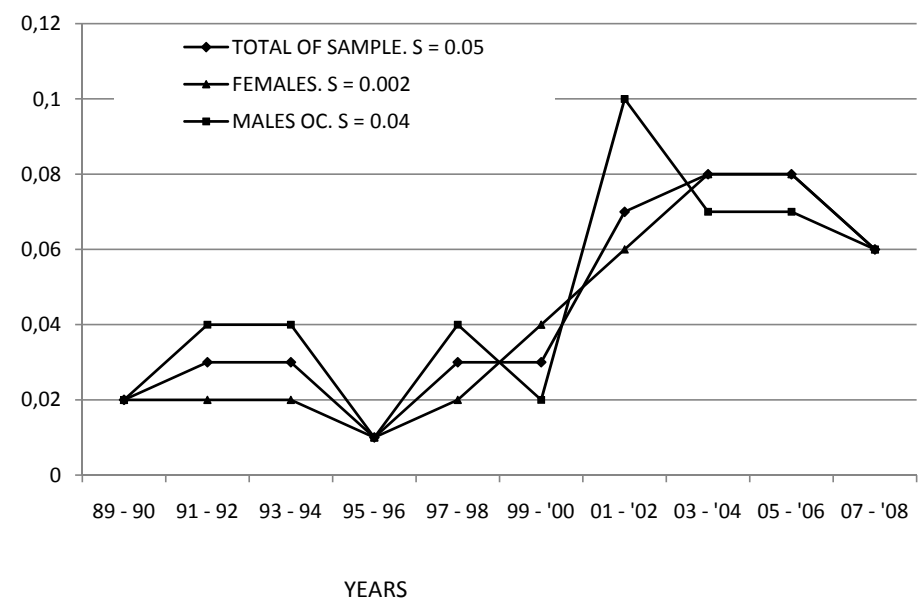

Fig. 1. Trends of the prevalence of oral cancer in a Mexican cohort (1989 - 2008). $\mathrm{S}=$ linear regression significance.

Prevalence (\%)

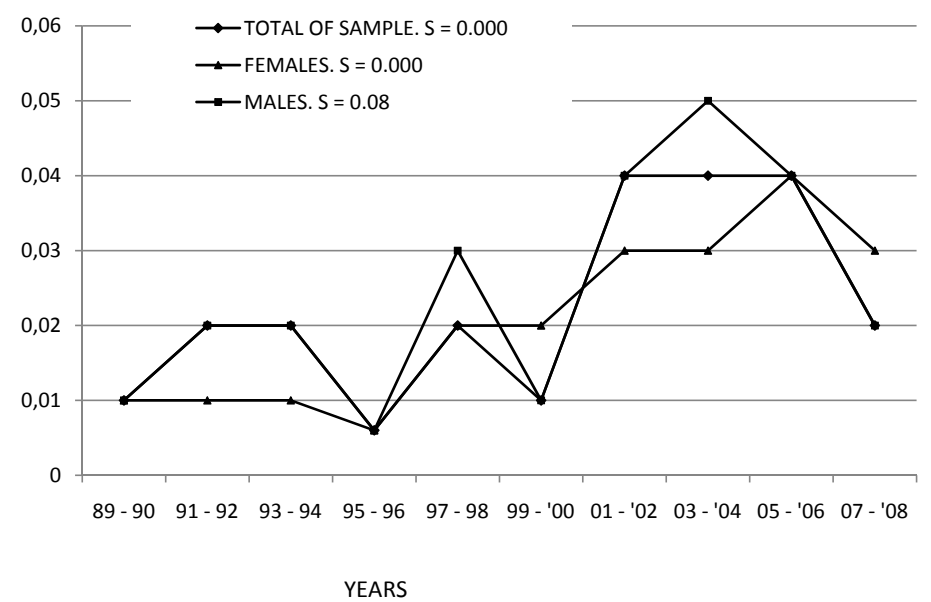

Fig. 2. Trends of the prevalence of oral squamous cell carcinoma in a Mexican cohort (1989 - 2008).

$\mathrm{S}=$ linear regression significance.

\section{Discussion}

The oral cancer represents $5 \%$ of all malignancies of whole body (5). However the frequency and prevalence of OCC varies in regard to social; demographical and geographical characteristics, e.g.: In southeast of Asia, including India, OCC is the most frequent type of cancer (6) while in Europe is engaged in the third place in frequency (7). In Mexico the epidemiological information regard OCC is scarce. The Oral Pathology Laboratory of the Dental School, National Autonomous University of México has a collection of approximately 40,000 head and neck biological samples collected over the last 40 years. It is considered as a national referral center for oral pathology. The attendance area of oral pathology laboratory is from Dental School of the National Autonomous University of Mexico. The teaching dental clinics of the Dental School offer more than 150,000 dental treatments annually and are considered as the most important dental service to open population in Mexico City. The population that is attending in the dental clinics is representative of the Mexico City population.

The incidence rate of OCC is arousing principally in females (5) closely related to the increase in the smoking habit by women. Our findings showed that the prevalence of OCC increased in the last decade, principally in 
females. The increase of OCC observed in the present report could have several explanations. It could reflect the increase in the number of Mexicans during the same period of time. The Mexican population growth from 81 millions of inhabitants in 1990 to 106.7 millions in 2008 (8). On the other hand, the increase could be a consequence of a major diffusion of health education programs towards general practice dentists to identify oral lesions suspected of malignancy. Another putative explanation could involve the risk factors for carcinogenesis. The most important risk factors for develops OSCC are smoking and chronic alcoholism $(9-11) .75 \%$ of all OSCC are related to one or both carcinogenic factors $(12,13)$. An increase in the consumption of tobacco and alcohol in young Mexicans has been reported (11, 14 16). The perception of Mexican youth about smoking is like a normal and socially acceptable behavior (16). An early exposure to tobacco and alcohol beverages due to a more permissive environment could be related to the increase of OSCC, specifically in females.

Recently a close relation between OSCC and human papilloma virus (HPV) infection has been reported (13, 17). To confirm if the HPV oral infection is related to the increase in the number of cases of OSCC identified in this report is necessary a research protocol designed ex-professo.

The demographical profiles of patients suffering OSCC have been well established, including a male predominance (7). The male:female ratio in the United States of America is 2:1 (5), while in Spain it is 7:1 (7). Previously it had been reported a male:female ratio 2:1 in Mexicans suffering OCC (13). Our results show a slightly female predominance (male:female ratio 1:1.1). If the trend toward increase of OSCC female cases continues, it is possible to suggest that in Mexicans more females than males will suffer OSCC in the next decades.

The relative risk to suffer cancer increases in relation to age. However an increase of people under 40 years old (with or without exposition to carcinogenic risk factors) suffering OSCC, has been reported in recent years $(1,2)$. If the cases of oral cancer in youth are isolated cases or if they are the consequence of a change in the demographical profiles it is not known. Our results did not show a time trend towards decrease the age at diagnoses. The mean age at diagnoses in Mexican females was 58 years very similar to reported to Brazilian women: 60.7 years old (11).

Due México is a developing country the optimization of the health institutions focused in the attention of oncologic patients is required. In México, the number of death attributed to oral cancer from 1979 to 2003 was 15,579 (18), therefore oral cancer is considered a public health problem. Our findings support the need to establish policies to prevent the exposition to risk factors of young people and concomitantly to establish programs specifically designed to the early identification of oral lesions suspected of malignancy. The general practice dentist should be awake of the possibility of identify OSCC in population that traditionally was not considered as high risk population to suffer oral cancer.

\section{References}

References with links to Crossref - DOI

1. Warnakulasuriya S, Mak V, Möller H. Oral cancer survival in young people in South East England. Oral Oncol. 2007;43:982-6.

2. Chow CW, Tabrizi SN, Tiedemann K, Waters KD. Squamous cell carcinomas in children and young adults: a new wave of a very rare tumor? J Pediatr Surg. 2007 ;42:2035-9.

3. Dahlstrom KR, Little JA, Zafereo ME, Lung M, Wei Q, Sturgis EM. Squamous cell carcinoma of the head and neck in never smoker-never drinkers: a descriptive epidemiologic study. Head Neck. 2008;30:75-84.

4. Dirección General de Planeación. Memoria UNAM. (cited 2009 Dec 4) Available from: http://www.planeacion.unam.mx/Memoria/ 5. Gillison ML. Current topics in the epidemiology of oral cavity and oropharyngeal cancers. Head Neck. 2007;29:779-92.

6. Rastogi T, Devesa S, Mangtani P, Mathew A, Cooper N, Kao R, et al. Cancer incidence rates among South Asians in four geographic regions: India, Singapore, UK and US. Int J Epidemiol. 2008;37:14760 .

7. Nieto A, Ramos MR. Rising trends in oral cancer mortality in Spain, 1975-94. J Oral Pathol Med. 2002;31:147-52.

8. Villagómez P, Bistrain C. Situación demográfica nacional. Consejo Nacional de Población. 2008. [updated 2008 Dic 15; cited 2009 Nov 23] Available from: http://www.conapo.gob.mx/publicaciones/ $\mathrm{sdm} / \mathrm{sdm} 2008 / 01 . p d f$.

9. Chang HW, Ling GS, Wei WI, Yuen AP. Smoking and drinking can induce p15 methylation in the upper aerodigestive tract of healthy individuals and patients with head and neck squamous cell carcinoma. Cancer. 2004;101:125-32.

10. Chen C, Ricks S, Doody DR, Fitzgibbons ED, Porter PL, Schwartz SM. N-Acetyltransferase 2 polymorphisms, cigarette smoking and alcohol consumption, and oral squamous cell cancer risk. Carcinogenesis. 2001;22:1993-9.

11. De Carvalho MB, Lenzi J, Lehn CN, Fava AS, Amar A, Kanda $\mathrm{JL}$, et al. [Clinical and epidemiological characteristics of squamous cell carcinoma of the oral cavity in women]. Rev Assoc Med Bras. 2001;47:208-14.

12. Thomas G, Hashibe M, Jacob BJ, Ramadas K, Mathew B, Sankaranarayanan $\mathrm{R}$, et al. Risk factors for multiple oral premalignant lesions. Int J Cancer. 2003;107:285-91.

13. Anaya-Saavedra G, Ramírez-Amador V, Irigoyen-Camacho ME, García-Cuellar CM, Guido-Jiménez M, Méndez-Martínez R, et al. High association of human papillomavirus infection with oral cancer: a case-control study. Arch Med Res. 2008;39:189-97.

14. Rasmussen-Cruz B, Hidalgo-San Martín A, Nuño-Gutiérrez BL, Hidalgo-Rasmussen $\mathrm{C}$. Tobacco consumption and motives for use in Mexican university students. Adolescence. 2006;41:355-68.

15. Gaitán Cepeda LA, Calderón Boni L, Martínez González M, Zamudio Gómez MA, Donahué Cornejo A, Villegas Ham J, et al. [Alcohol drinking patterns in dental students]. Salud Publica Mex. 2004;46:282-3.

16. Thrasher JF, Bentley ME. The meanings and context of smoking among Mexican university students. Public Health Rep. 2006;121:578-85.

17. Closmann JJ. The human papilloma virus, the vaccines, and oral and oropharyngeal squamous cell carcinoma: what every dentist should know. Gen Dent. 2007;55:252-4.

18. Anaya-Saavedra G, Ramírez-Amador V, Irigoyen-Camacho ME, Zimbrón-Romero A, Zepeda-Zepeda MA. Oral and pharyngeal cancer mortality rates in Mexico, 1979-2003. J Oral Pathol Med. 2008;37:11-7. 